\title{
The Massive Development of Web-Based Office Applications
}

\author{
Esa Hanis Lam'an ${ }^{1}$, Agus Setiawan ${ }^{2 *}$
}

\author{
${ }^{1}$ Student of Informatics Engineering Department, Universitas Muhammadiyah Magelang, Indonesia \\ ${ }^{2}$ Department of Informatics Engineering, Universitas Muhammadiyah Magelang, Indonesia \\ *Corresponding author. Email: setiawan@ummgl.ac.id
}

\begin{abstract}
The development of information and communication technology is no longer unstoppable because of the demands it demands. The use of information and communication technology goes into all fields of service and goods industries. The internet has become a trigger of developments in information and communication technology. Just ask an office application that utilizes the internet to connect one office with another office. Website technology allows applications to be opened on all kinds of hardware platforms such as computers, handheld computers, tablets, and smartphones. Due to the development of hardware in computers, this also changed the basis of office applications. Office applications will be more flexible if they are based on a website because they can be opened quickly from any hardware platform with only a browser and internet connection. The massive development of Website-based office applications is indeed a need to increase the effectiveness and efficiency of a company's production process. This office application will continue to experience developments that adjust to the industrial revolution of 4.0 and the next generation.
\end{abstract}

Keywords: world, Indonesia, administrative information systems performance, information technology,

website

\section{INTRODUCTION}

Various types of digital form information technology are becoming popular and in demand by the world community, the internet one of them. This technology is very beneficial for many people because it has many benefits. The internet was only used to find data, and now the internet can be used by smartphone and computer users to communicate, find news, and do business. Nearly a third of the world's population has used the internet in their daily lives [1].

According to the 2016 survey data released by the Indonesian Internet Network Providers Association (APJII), 132.7 million Indonesians are connected to the internet. It was stated that internet media users in Indonesia continued to grow every year. According to 2018 survey data released by the Association of Indonesian Internet Network Providers (APJII), it was stated that internet media users in Indonesia continued to increase every year from 2017 to only 143.26 million in 2018 , increasing to 171.17 million Indonesians connected with internet [2]. Not much different from the development of the world internet, which reached 4.5 billion users from a total of 7.7 billion world population [3]. Ease of access to devices to the internet and the ease of having an internet device that makes the growth of Indonesian internet users increase [4], [5]. Based on the data above, the presence of the internet is growing from year to year, meaning that the internet has become a bridge for the people of Indonesia and the world in carrying out various activities.

There are the top 25 countries with the highest number of internet users in the world. Until now, it is known that China is the country with the most internet users, with a total of 736.2 million users in 2017. In Indonesia alone, internet users continue to increase from year to year with an incredible percentage increase. Currently, Indonesia is already in sixth place after Japan, with 112.6 million internet users, and ranked 25th by South Africa with 29.2 million internet users [6].

Information technology is a technology that combines computers with high-speed communication lines, which carry data, voice, and video. It can be concluded that information technology is the science of organizing events to manage information so that information can be searched easily. Information technology gave rise to a system that we commonly call information systems [7].

The information system is a system within an organization that meets the needs of daily transaction processing, supports operations, is managerial and strategic activities of an organization, and provides certain external parties with the necessary reports [8]. The administration has an understanding of administration in the form of activities to record, collect, and store activity or the results of activities to assist leaders in making decisions [9]. Administrative information systems are systems that process data and transactions to produce information that is useful for planning, controlling, and operating finances. The existence of an administrative information system for accounting transaction work becomes more accessible and faster and can minimize errors in the preparation of financial statements. For example, offices use information technology as a need to support the advancement of administrative information systems in finance [10].

The development of office information systems is balanced with the development of massive information technology 
that does not require a long time. This change requires its users to continue to learn to use the application to increase its productivity. The company owner will continue to develop information technology to support the effectiveness and efficiency of each process of its activities. Therefore, this paper aims to review and analyze the development of office applications before the Web-based up to now, which is almost all Web-based.

\section{METHOD}

The methodology in the implementation of this research is to conduct a literature study by collecting data from internet sources, books, to analyze the development of the office administration information system website currently in use.

\section{RESULTS AND DISCUSSION}

\subsection{Information Technology Development}

The development of information technology can improve performance and make various activities that can be carried out quickly, precisely, and accurately so that productivity ultimately increases. Emerging new patterns of life, from waking up to going to sleep, have been influenced by various needs electronically. This pattern of life is known as e-life, meaning that now various letters that begin with the prefix e such as e-government, e-commerce, ecommerce education, e-medicine, e-laboratory, and others, all of which are electronic-based. [11]

Information Technology is a technology used to process data, including processing, obtaining, compiling, storing, manipulating data in various ways to produce quality information, namely information that is relevant, accurate and timely, which is used for personal, business, government and is strategic information for decision making. This technology uses a set of computers to process data, a network system to connect one computer to another as needed, and telecommunications technology is used so that data can be spread and accessed globally. [7]

\subsubsection{The Role of Information Technology}

Our lives in the future, information technology, and telecommunications are the most influential fields. The role of information technology applications is to provide information such as health, education, government, and economic information. Collaborative activities between individuals or groups with one another without knowing the limits of distance and time, country, race, economic class, ideology, or other factors that can inhibit the exchange of ideas. Information technology plays a role in fields such as [9]:

\subsubsection{Education sector (e-education).}

Future education is predicted to be flexible, open, and accessible to anyone regardless of the type, age, or previous educational experience [12]. The use of services to students and parents or guardians of students will also use information technology services [4]. The predictions from the experts above can be concluded that with information technology, future education will be more open and twoway, diverse, and related to work productivity and competitiveness.

The trends of the world of education in Indonesia in the future are:

a. The development of e-education by way of distance learning. It can make it easier to conduct open and distance education activities.

b. Sharing of shared resources between educational or training institutions via the internet

c. Libraries \& other educational instruments (teachers, laboratories) have changed functions to become sources of information

d. The use of interactive information technology devices, such as smartphones, laptops, tablets, and PCs, gradually replace TV and radio to conduct learning activities or what is commonly referred to as e-learning. The development of information technology in the field of education, it is now possible to hold distance learning activities using internet media to connect between students and lecturers, view student grades online, check finances, view class schedules, send assignment files given by lecturers and so on, all of that can already be done [13].

\subsubsection{Finance and Banking}

The rapid development of information technology brings changes and has a significant impact on all areas of human life. This development is due to humans, organizations, companies, and agencies always need accurate, fast, and accurate information. All these needs can be fulfilled by information technology in computerized systems. Offices or companies that use information systems in banking and finance. Causing users in the financial sector who still use ancient administration websites such as visual basic or Delphi are now turning to websites because users need an effective and efficient data processing system to support activities and decision making that is fast, and accurate. Optimizing data processing systems by building web-based office applications can improve, develop, and improve the effectiveness and efficiency of an office or company [14].

\subsubsection{In the Field of Government (e-government)}

E-government is the use and utilization of information technology by government and services for the community. Improve work efficiency in the internal environment and provide public services effectively and efficiently. It is a process of transactions between the public and the government through internet systems and networks, more commonly known as WWW (world wide web). The use of information technology then produces new forms of 
relationships such as $\mathrm{G} 2 \mathrm{C}$ (Government to Citizen), G2B (Government to Business), G2E (Government to Employees) and G2G (Government to Government) [11]. Government to Citizen (G2C) is an information technology that has aim to strengthen relations or interactions between the government and the people and also to facilitate the public in finding all kinds of important information about government. Government to Business (G2B) is a model of the relationship between government and business. Because it really needs a very good relationship between the government and business people. The purpose of Government to Business (G2B) is for the convenience of doing business with the business community. Government to Government (G2G) is a government web that is formed and has the aim to fulfill several types of information needed between one government and another government, with the aim of being able to facilitate cooperation between related governments. Government to Employees (G2E) is a type of relationship directed at government employees as improving performance and also for the welfare of employees who work in one of the government institutions.

\subsubsection{Benefits of E-Government}

The benefits of E-Government are divided into several points; below are the benefits of E-Government explanation as follows:

a. To be able to improve the service level of government for stakeholders, the main one is in terms of performance effectiveness and efficiency in all fields of life and the state.

b. To increase the transparency of control and also accountability in the administration of government, namely in the context of applying the concept of Good Corporate Governance.

c. In order to significantly reduce the total administration, relations, and interaction costs that can be incurred by the government for the benefit of daily life.

\subsubsection{Information system development program in Indonesia}

Information systems development program (program indicator 16.6.01) information systems needed to increase the entry of information science and technology that occur in the international world, facilitate the exchange and dissemination of science and technology information, as well as improve planning systems, management, monitoring of activities and progress science and technology [15]. The number of costs incurred by the government to conduct studies, research, and application of mastery in the field of information technology during the $1997 / 1998$ to 2001 fiscal year can be seen in the table below. The table below shows the APBN (pure rupiah) for information system development programs, fiscal years $1997 / 1998$ to 2001 Table 1. State Budget for the development of information systems from 1997/1998 to $2001[11]$.
Table 1 Budget for the development of information systems

\begin{tabular}{|c|l|c|}
\hline No & \multicolumn{1}{|c|}{ Year } & Budget (Million) \\
\hline 1 & $1997 / 1998$ & 28.235 \\
2 & $1998 / 1999$ & 32.622 \\
3 & $1999 / 2000$ & 24.538 \\
4 & 2000 & 52.236 \\
5 & 2001 & 30.956 \\
\hline
\end{tabular}

\subsection{Analysis of the Development of Administrative Information Systems in the Past}

The development of information systems has resulted in administrative Web-Based Office Applications and is used by agencies or companies, namely Visual Basic and Delphi. It was once used as an office application and now goes to the website. Definition as

\subsubsection{Visual Basic}

According to [16], Visual Basic is the name of a programming language. Programming languages are languages that can be understood by computers to perform certain tasks. So, it can be concluded that Visual Basic has a function as a tool for making various computer programs. Visual Basic has a very reliable application programming software maker, Visual Basic 6.0. Some of the abilities or benefits of Visual Basic include:

a. To create a windows-based application program.

b. To create program helper objects, ActiveX controls, Help files, Internet applications, and so on.

c. Test the program (debugging) and produce a suffix ending in EXE that is executable, or can be directly run

\subsubsection{Delphi}

According to [17], Delphi is an IDE compiler for the Pascal programming language and software development used to design an application. Delphi can also be regarded as programming that uses visualization as well as visual basic programming languages. However, Delphi uses the same language like Pascal. Delphi also uses the concept of objectoriented (OOP).

In general, the Delphi language is only used to develop desktop applications. However, after developing, Delphi is a general-purpose. This program has a role in creating window applications and programs based on client or server networks. Delphi can also design application-based programs and design .Net programs.

The advantage of this programming language is that it facilitates distribution and also minimizes problems associated with versioning. Apart from that, compiler optimization is fast. This programming language can be used on multiplatform (Windows, Linux, IOS, and Android), and this program can also compile into portable applications.

The weakness of this language itself is that accessing platforms and libraries requires header filters translated in 


\section{CONCLUSION}

Pascal language. There are language problems with platform documentation, and the accompanying techniques are difficult to find in Pascal Language.

\subsection{Analysis of the Development of Administrative Information Systems Website Today}

\subsubsection{The website}

"Website is an interconnected web page which generally contains a collection of information in the form of text data, images, animations, audio, video, or a combination of everything that is usually made for the personal, organization, and company. From the understanding of the website can be divided into 2 , namely, the web is static and dynamic. "[18].

a. Static Website: a website that has pages that do not change. The meaning is to make changes to a page done manually by using code, which is the structure of the website.

b. Dynamic Websites: websites that are structurally destined to update as often as possible. Usually, the main jam that can be accessed by users in general also provided a backend page for editing content from the website. Common examples of dynamic websites are news websites or web portals on which there are news, polling, and other facilities so that the topic being discussed does not get off track.

\subsubsection{Administrative Information System}

All companies and agencies need administrative information systems. Like the financial office at the Magelang City Transportation Office. The problem of hard copy data that is piling up or difficult to find because it is too much so that it takes time makes it difficult for financial employees to find a recap of financial data for the needs of financial transaction reports. To produce all accurate and precise reports become relatively long.

The existence of these problems requires the existence of an information system in financial transactions. Financial data reports at the Magelang City Transportation Department's financial office, which are still conventional, have not been able to produce all reports optimally. Therefore, based on the problems faced, to overcome this need, a system that can overcome the problems that occur with a web-based financial management data administration information system.

Then the financial transaction report can efficiently search data, facilitate data recapitulation, fund submission processes, and print at any time based on information technology. Making it easier to make decisions for the purposes of procurement and financial data is also safer. Because in making this web-based administrative information system, using a login to access the system so that the data contained in the system can be controlled and secure.
The development of the use of information and communication technology rapidly continues to lead to the use of artificial intelligence. This is in accordance with the development of industry 4.0. Current data is elementary to obtain for further use, which is to make decisions and policies to be more targeted. The use of website-based information systems is crowded, and people are doing it in droves. Businesses, as well as in the world of Education, prefer website-based information systems to get data transfer speeds that do not recognize space and time.

\section{ACKNOWLEDGMENT}

I am very grateful for friends who have helped to complete this research. Also, I am very grateful to families who always encourage and always pray for the best for this research.

\section{REFERENCES}

[1] F. V. Sudjatmika, "Pengaruh Harga, Ulasan Produk, Kemudahan, dan Keamanan Terhadap Keputusan Pembelian Secara Online di Tokopedia.com," Agora, vol. 5, no. 1, pp. 1-7, 2017, [Online]. Available: http://studentjournal.petra.ac.id/index.php/manajemenbisnis/article/view/5227\%0Ahttp://studentjournal.petra. ac.id/index.php/manajemenbisnis/article/view/5227/4814.

[2] APJII, "Penetrasi \& Profil Perilaku Pengguna Internet Indonesia Tahun 2018,” Jakarta, 2019.

[3] M. M. Group, "World Internet Users and 2020 Population Stats," Internet World Stats, 2020. https://www.internetworldstats.com/stats.htm (accessed Apr. 22, 2020).

[4] A. Setiawan and R. Widaryanto, "Mobile CRM student-parent information system," IOP Conf. Ser. Mater. Sci. Eng., vol. 403, p. 012076, Oct. 2018, doi: 10.1088/1757-899X/403/1/012076.

[5] A. Setiawan, E. U. Artha, E. R. Arumi, Sunarni, A. Primadewi, and S. Nugroho, "Task Analysis of Facebook users on Frequently used Menus," J. Phys. Conf. Ser., vol. 1179, p. 012019, Jul. 2019, doi: 10.1088/1742-6596/1179/1/012019.

[6] S. Setti and A. Wanto, "Analysis of Backpropagation Algorithm in Predicting the Most Number of Internet Users in the World," J. Online Inform., vol. 3, no. 2, p. 110, 2019, doi: 10.15575/join.v3i2.205. 
[7] R. Pamungkas, "Perancangan Sistem Informasi Pembayaran Administrasi SMK Negeri 1 Jiwan," INTENSIF, vol. 1, no. 2, p. 129, 2017, doi: 10.29407/intensif.v1i2.799.

[8] F. A. Haryoguno, "Analisa dan Perancangan Sistem Informasi Administrasi Member dengan Metodologi Berorientasi Obyek pada Rockstar Gym Indonesia," Indonesia. J. Inf. Syst., vol. 1, no. 5, pp. 79-86, 2018, [Online]. Available:

http://jom.fti.budiluhur.ac.id/index.php/IDEALIS/articl e/view/988.

[9] D. Istiana and I. Ariyati, "Sistem Informasi Akuntansi Perusahaan Dagang Menggunakan Zahir Accounting Versi 5.1.," Inf. Manag. Educ. Prof. J. Inf. Manag., vol. 2, no. 1, pp. 11-20, 2017, [Online]. Available: http://ejournal-

binainsani.ac.id/index.php/IMBI/article/view/599.

[10] K. S. Ratnasih, E. Sujana, and N. K. Sinarwati, "Pengaruh Kecanggihan Teknologi Informasi, Partisipasi Pengguna, dan Kemampuan Pengguna Terhadap Kinerja Sistem Informasi Akuntansi pada PT PLN (Persero) Area Bali Utara (Kantor Pusat), J. Imiah Akunt. Mhs. Akunt. UNDIKSHA, vol. 7, no. 1, 2017, doi: 10.23887/jimat.v7i1.9463.

[11] W. Wardiana, "Perkembangan Teknologi Informasi di Indonesia," in Seminar dan Pameran Teknologi Informasi, 2002, no. 9, pp. 1-6, doi: 10.1007/BF02191578.

[12] O. W. Windrick, K. B. Walela, and O. A. Sande, "Factors Influencing Academic Performance Of Standard Eight Girls In National Examinations In Public Primary Schools A Case Of Matungu Division.," Int. J. Sci. Technol. Res., vol. 4, no. 6, pp. 46-58, 2015.

[13] V. D. Wicaksono and P. Rachmadyanti, "Pembelajaran Blended Learning melalui Google
Classroom di Sekolah Dasar," in Seminar Nasional Pendidikan PGSD UMS \& HDPGSDI Wilayah Jawa, 2017, pp. 513-521, [Online]. Available:

https://publikasiilmiah.ums.ac.id/bitstream/handle/1161 7/9144/44.pdf? sequence $=1$.

[14] M. Bakhar, M. Khambali, and U. Albab, "Pengembangan Sistem Informasi Pengelolaan Alat Tulis Kantor Pada Politeknik Harapan Bersama Tegal Berbasis Framework Yii,” J. Inform. J. Pengemb. IT, vol. 2, no. 2, pp. 96-101, 2017, [Online]. Available: http://ejournal.poltektegal.ac.id/index.php/informatika/a rticle/view/607.

[15] Pusat Pengkajian dan Penerapan Teknologi Informasi dan Elektronika, "Indikator Teknologi Informasi dan Komunikasi Tahun 2001,” Jakarta, 2001. [Online]. Available:

http://bebas.ui.ac.id/v17/com/ictwatch/data/siti2001.pdf

[16] M. Kristina and S. Sulantiwi, "Sistem Pendukung Keputusan Menentukan Kualitas Bibit Ikan Guramedi Pekon Sukosari menggunakan Aplikasi Visual Basic 6.0," J. TAM (Technology Accept. Model., vol. 4, 2015, [Online]. Available:

http://ojs.stmikpringsewu.ac.id/index.php/JurnalTam/art icle/view/34.

[17] M. H. Abdullah and A. Samad, "Pengaruh Sistem Informasi Keuangan Desa (SISKEUDES) Terhadap Kinerja Kepala Desa (Studi Kasus Desa Tokaka, Kecamatan Gane Barat Utara, Kabupaten Halmahera Selatan)," IJIS-Indonesia J. Inf. Syst., vol. 3, no. 2, 2019, doi: 10.1021/jp5128578.

[18] A. Rochman, A. Sidik, and N. Nazahah, "Perancangan Sistem Informasi Administrasi Pembayaran SPP Siswa Berbasis Web di SMK AlAmanah," J. Sisfotek Glob., vol. 8, no. 1, pp. 51-56, 2018, doi: 10.1002/ijc.23959. 